IZADP No. 1954

Educational Differences in the Migration Responses of Young Workers to Local Labor Market Conditions

Abigail Wozniak

J anuary 2006 


\title{
Educational Differences in the Migration Responses of Young Workers to Local Labor Market Conditions
}

\author{
Abigail Wozniak \\ University of Notre Dame \\ and IZA Bonn
}
Discussion Paper No. 1954
January 2006

IZA
P.O. Box 7240
53072 Bonn
Germany

Phone: +49-228-3894-0

Fax: +49-228-3894-180

Email: iza@iza.org

\begin{abstract}
Any opinions expressed here are those of the author(s) and not those of the institute. Research disseminated by IZA may include views on policy, but the institute itself takes no institutional policy positions.
\end{abstract}

The Institute for the Study of Labor (IZA) in Bonn is a local and virtual international research center and a place of communication between science, politics and business. IZA is an independent nonprofit company supported by Deutsche Post World Net. The center is associated with the University of Bonn and offers a stimulating research environment through its research networks, research support, and visitors and doctoral programs. IZA engages in (i) original and internationally competitive research in all fields of labor economics, (ii) development of policy concepts, and (iii) dissemination of research results and concepts to the interested public.

IZA Discussion Papers often represent preliminary work and are circulated to encourage discussion. Citation of such a paper should account for its provisional character. A revised version may be available directly from the author. 


\section{ABSTRACT}

\section{Educational Differences in the Migration Responses of Young Workers to Local Labor Market Conditions}

It is unclear whether educational disparities in internal migration levels reflect important economic differences or simply different consumption choices. I answer this question empirically by testing for educational differentials in the likelihood that young workers undertake and succeed at arbitrage migration. I find that young college graduates are two to five times more likely than less educated workers to reside in a state with high labor demand at the time they entered the market. Among college graduates, cross-state migration by college graduates equalizes the wage impact of early career labor demand shocks in their home states. This is not true for less educated workers. The lack of wage convergence is most severe for cohorts who entered the labor market during periods of high spatial variation in state conditions and low national employment growth. My results are consistent with theories of educational differences in migration that assume less educated workers are credit constrained, and cast doubt on several other explanations for the difference.

JEL Classification: J6

Keywords: internal migration, local labor markets, education

Corresponding author:

Abigail Wozniak

Department of Economics and Econometrics

Flanner 441

University of Notre Dame

Notre Dame, Indiana 46556

USA

Email: a_wozniak@nd.edu

\footnotetext{
* I thank the Social Sciences Research Council, the Thomas Cochran Dissertation Fellowship in Economic and Business History, and Harvard University for support during the course of this research. I have benefited from numerous helpful conversations with Lawrence Katz, Claudia Goldin, David Cutler, Caroline Hoxby, Richard Freeman, Carola Frydman, Matthew Gentzkow, Adriana LlerasMuney, Ofer Malamud, Raven Saks, Tara Watson, Neal Wozniak and seminar participants at the Harvard Economics Department Labor and Public Economics Lunch, the University of Notre Dame, Williams College, the Federal Reserve Bank of Philadelphia, and IZA. All errors, omissions, and oversights are my own.
} 
Within the geographically mobile U.S. labor force, highly educated workers are much more likely than others to migrate over long distances. For example, Figure 1 shows that college graduates are nearly twice as likely as their high school graduate peers to have moved out of their states of birth. ${ }^{1}$ The long literature on migration recognized this disparity over a century ago, but explanations for the gap have remained largely at the level of conjecture. ${ }^{2}$ Specifically, it is unclear whether divergent internal migration levels reflect important economic differences across education groups or simply different consumption choices. One test of whether high levels of geographic mobility among the most educated stem from personal preferences and higher incomes or from other economic factors is to ask whether workers with different levels of educational attainment do move when they should. The first part of the paper provides such a test. I examine whether highly educated workers are better at moving between local labor markets to take advantage of geographic differences in wage levels and employment conditions. The paper then evaluates several explanations for why different types of labor allocate themselves more or less efficiently in our economy.

The motivation for studying this question is twofold. First, labor mobility plays a critical role in enabling sub-national economies to adjust following local demand shocks within the U.S. ${ }^{3}$ Differential responsiveness across skill groups may affect how fast and to what degree local economies return to pre-shock wage and unemployment levels. Understanding differential responses by skill groups may also help resolve outstanding puzzles in the economic adjustment

1 By the time they reach their early twenties. This mobility differential between high school graduates and college graduates appears in the data going back to 1940 (although only data back to 1970 are shown in Figure 1) and generally holds regardless of the mobility measure used, e.g. moved out of birth state, moved out of birth county, moved between states in the last five years, etc.

2 For an overview of the main questions in this literature, see Greenwood (1975). For a review of the literature's findings, and for a citation on the mobility gap from the late 1800s, see Greenwood (1997). Borjas (2004) discusses some puzzles related to differences in geographic mobility.

3 See Blanchard and Katz (1992); Hanson and Slaughter (1999); and Borjas (2001). Labor mobility is much less important for arbitraging local labor demand variation in Europe. See Decression and Fatas (1995), Eichengreen (1993), and Puhani (1999). 
literature such as the persistence of geographic variation in unemployment levels. ${ }^{4}$ Second, constraints on the ability to make arbitraging moves may negatively affect the welfare and lifetime incomes of individual workers and their families. Geographic mobility itself may be an important determinant of the greater economic success enjoyed by more highly educated workers. Schultz (1961) even argues that internal migration should be viewed as a form of human capital investment. Little is known about the role of mobility in determining labor market outcomes, but authors who have explored the question find that mobility helps more educated workers in a number of ways. ${ }^{5}$

To test whether highly educated workers are more likely to migrate in response to early career local labor market conditions, I construct a demand-driven measure of state labor market conditions that workers most likely faced at the time they entered the labor force. This measure uses an increasingly popular average of state employment growth across industries in which statelevel employment in an industry is weighted by national employment growth in that industry to produce an estimate of changes in employment due to solely demand factors. ${ }^{6}$ This procedure purges state employment growth of changes resulting from labor supply shifts. My measure aggregates demand-driven state employment growth into average employment growth during the years a birth cohort was ages 18 to 22, which I call the Labor Demand Index.

My first set of estimates tests whether early career state labor market conditions, as measured by the Labor Demand Index, affect the probability that workers of different education levels live in the state several years later. I model this choice problem using a conditional logit that allows workers to choose a location from among all 50 states. Using microdata from the 1980, 1990 and

\footnotetext{
${ }^{4}$ Lkhagvasuren (2005) develops and simulates a structural model of regional unemployment that arises in spite of high migration levels.

5 For example, Topel (1986) finds that more mobile workers are insulated from the wage effects of transitory changes in local conditions. Bound and Holzer (2000) argue that migration of more educated workers from low-wage to high-wage areas in the 1980 s explains some of the relative labor market success of skilled workers during this decade. Basker (2003) explores long-distance job search techniques of more and less educated workers.

${ }^{6}$ This measure was first proposed by Bartik (1991) and has been employed by Blanchard and Katz (1992), Bound and Holzer (2000), and others.
} 
2000 U.S. Censuses, I match workers observed in their late twenties to the range of state conditions they faced in their early twenties. I find that better early career economic conditions in a state disproportionately attract highly educated workers. An increase in state labor demand of one percentage point relative to a state trend during a cohort's labor market entry years increases the probability that high school graduates reside in the state by $2-3 \%$ while the effect for college graduates is several times greater, in the range of $6-11 \%$. Cross-state migration by college graduates fully equalizes the wage impact of early career labor demand shocks in their home states, but the same is not true for less educated workers.

I make two significant contributions to the literature on labor mobility in this paper. First, I provide a direct comparison between the labor supply elasticities with respect to state labor market conditions for more and less educated workers. Young college graduates are two to five times as responsive as high school graduates to a given change in state labor demand. Earlier studies typically focused on the relationship between relative labor supplies and relative wages, which obscures educational differences in the pure migration response to labor demand.

Second, and more importantly, I test competing theories about why education groups differ in their propensity to undertake arbitrage migration. Direct tests of these theories are extremely rare in the literature. ${ }^{7}$ I show that less educated workers are least likely to make arbitraging moves when national conditions most urgently require it: when spatial variation in demand shocks is large. During times of relatively low variation in demand shocks across states, less educated workers are as successful at arbitraging shocks as the highly educated. This outcome is consistent with an important role for credit constraints in the migration choices of less educated workers and implies that modest relocation subsidies could significantly reduce the spatial mismatch between less educated workers and labor demand.

\footnotetext{
7 To my knowledge, none exist with respect to arbitrage migration.
} 
The paper proceeds in seven sections. In Section II, I present a simple choice framework to highlight ways in which education might affect arbitraging mobility decisions and outline a test to distinguish competing theories of educational differences in arbitrage migration. I discuss the data on individual labor market outcomes, geographic mobility, and education that I extract from the 1980-2000 U.S. Censuses of Population in Section III. I also describe my primary measure of early labor market conditions in more detail. I examine the migration response of different education groups to local conditions and test for persistent effects of early conditions on various labor market outcomes in Sections IV and V. In Section VI, I consider reasons that the mobility response differs across education groups. I conclude in Section VII.

\section{The Economics of Individual Mobility Decisions}

State and local labor markets within the United States are best described as small open economies. There is a high level of labor mobility between them as well as large differences in industrial composition across them. ${ }^{8}$ In a simple model of labor market clearing in a small, open economy, wage changes caused by shocks to local labor demand are quickly arbitraged away as workers flow into areas of high demand from areas of low demand.' The operation of these equalizing flows is illustrated in Figure 2, which shows three labor market clearing equilibria in a small, open labor market with homogeneous workers. Local labor demand is downward sloping and the equilibrium wage is $w^{*}$, where $w^{*}$ is relative to other U.S. markets. In the long-run, labor supply to this market is perfectly elastic, because the U.S. economy as a whole can send or receive large numbers of workers to or from any local market. In the short-run, however, the labor supply curve

8 Borjas, Freeman and Katz (1996) show that labor flows freely between areas of the U.S. Lewis (2003) shows that this is not the case with capital; industrial composition across areas adjusts too slowly to be consistent with open economy models.

9 In the later empirical analysis, I use states as the units which define local labor markets, and I will use the terms state and local labor market interchangeably. 
is upward sloping. Workers respond to shocks to labor demand, but migration only returns the local wage to $w^{*}$ after some time.

To understand how an individual worker decides to move between local labor markets following a set of unequal demand shocks to these markets, consider the worker's simple costbenefits calculation. For a worker residing in state $s^{*}$, the choice problem is the following:

$$
\underset{s \in S}{\arg \max } U\left(c_{s}\right)=\underset{s \in S}{\arg \max }\left\{\sum_{t}\left[E\left(w_{s t}^{j}\right) / p_{s t}-c_{s, s^{*} t}^{j}\left(1 \mid s \neq s^{*}\right)\right] \delta^{j}\right\}-\alpha_{s, s^{*}}^{j}\left(1 \mid s \neq s^{*}\right)
$$

where $s$ indexes the 50 states, $j$ indexes education groups, $c$ is consumption, $w$ is the nominal wage in state $s, p$ is the price level in $s, c$ and $\alpha$ are costs a worker must incur if he chooses to supply labor in a state other than his current state $s^{*}$, and $\delta$ is the worker's discount rate.

The utility-maximizing worker simply weighs a stream of expected future benefits (in the form of wages) against a stream of costs plus the one-time moving cost $\alpha$. If expected benefits exceed costs, the worker moves across local markets. The probability that a worker makes such a move is increasing in the expected wages available in states $\mathrm{s} \neq \mathrm{s}^{*}$. To see this, simplify Equation (1) by assuming that the cost $c$ is the same in every period and is independent of the destination and origination state pair $\left(s, s^{*}\right)$. Assume that $\alpha$ is similarly independent of the migration route and that prices do not differ across states. Then the probability that a worker chooses to supply labor in state $s \neq s^{*}$ depends on conditions in $s$ as well as conditions in all other states $-s$ in the following way:

\section{(2) $\operatorname{Pr}\left(\right.$ choose $\left.s \neq s^{*}\right)=$}

$$
\operatorname{Pr}\left[\sum_{t} E\left(w_{s t}^{j}\right)-\frac{c^{j}}{1+\delta^{j}}-\alpha^{j}>\sum_{t} E\left(w_{s^{* t}}^{j}\right) \quad \text { and } \quad \sum_{t} E\left(w_{s t}^{j}\right)>\sum_{t} E\left(w_{-s t}^{j}\right)\right] \quad \forall s,-s \neq s^{*}
$$

A positive (negative) shock to expected wages in state $s$ increases (decreases) the probability that $s$ is the selected state. This is a standard choice problem, like those considered by McFadden (1974).

There is no unambiguous theoretical basis for a particular relationship between education and the labor supply response to changes in local economic conditions. Many stories can be told 
that tip the scales in favor of either more or less educated workers. ${ }^{10}$ Rather, I answer this question empirically by testing whether a given shock to local labor demand in $s$, which leads to an increase in expected wages if migration is not immediate through the mechanism in Figure 2, leads to differential changes in the probabilities that workers from the $j$ education groups choose to reside in $s .{ }^{11}$ That is, I test whether the elasticity of local labor supply differs across education groups.

Although Equation 2 does not provide a prediction about the relationship between educational attainment and local labor supply elasticities, it does—when combined with the arbitrage model of Figure 2-imply a test of three competing theories about why more educated workers might be more responsive to spatial variation in labor market opportunities. One explanation assumes that less educated workers are credit constrained, while more educated workers are not. As a result, less educated workers are unable to finance cross-state moves when their current incomes are too low, even if such moves would lead to wage gains sufficient to cover moving costs. A second explanation assumes that less educated workers have poor information about distant opportunities and fail to undertake moves simply because they are unaware of higher wages elsewhere. A final explanation argues that the net gains from moving are higher for the more educated, either due to lower psychic costs from moving or due to the fact that absolute income gains are likely to be higher for high earners. ${ }^{12}$

\footnotetext{
${ }^{10}$ For example, less educated workers may acquire less firm-specific human capital on their jobs and thus have a smaller investment to lose by moving away from an area in the event of a downturn. This lowers the stream of costs they face and increases the likelihood that the expected value from a move exceeds the expected stream of wages in their current state. Alternatively, more educated workers may have the lower stream of costs if they have better long-distance networks of family and friends. And so on.

11 Shocks refer to a proportional change in wages that is the same across education groups. These represent equal productivity increases or decreases for all education groups, which seems realistic given that I am considering short run fluctuations in local labor demand.

12 This explanation groups a number of observationally equivalent (in this framework) stories, including greater reliance on family and social networks among the less educated and mitigating effects of housing prices that disproportionately increase the buying power of less educated families in declining areas. For a discussion of this last point, see Glaeser and Gyourko (2001). It also includes the classic theory of fixed moving costs described by Shultz (1961). Since a given percentage change in wages following migration from a low demand to a high demand area means that the absolute wage gain for less educated migrants will only exceed the cost of moving when the difference in
} 
Using the framework of Equation 2 and Figure 2, it is possible to separate these three theories according to their predictions about the conditions under which more and less educated workers should differ in their responsiveness to spatial variation in labor demand shocks. If less educated workers are credit constrained, then wage convergence is more likely when spatial variation in demand shocks is low and aggregate employment probabilities are high. ${ }^{13}$ For example, consider two regions, $\mathrm{A}$ and $\mathrm{B}$. If $\mathrm{A}$ receives a small negative shock to labor demand and $\mathrm{B}$ receives a positive shock, workers who can afford to will move from A to B. If the shock to A is small, then the expected wage decrease in A will also be small. Enough of the population in A can still finance a move to $\mathrm{B}$, and the small amount of migration necessary to arbitrage away these wage differences will occur. If the shock to A is large, however, then the decrease in expected wages in A will be large and the number who can afford to move from A to B will no longer be sufficient to generate wage convergence across the two areas. Alternatively, if less educated workers simply have poor information about opportunities in other markets, then convergence will not hold regardless of the amount of spatial variation in local conditions. Finally, if the net gains from moving are smaller for less educated workers, then a greater degree of spatial variation should encourage migration among this group. Convergence should emerge when the potential gains from moving are highest. I use information on wage convergence across cohorts who experienced different aggregate employment conditions and levels of spatial variation in state labor markets to test these theories in Section VI.

\section{Empirical Methods and Data}

I focus on the responses of early career workers to short-run changes in state labor market conditions for a number of reasons. Early in their careers, workers are likely to be most similar in

conditions across states is large. More educated workers, for whom a percentage increase in wages translates into a larger absolute gain, will find it worthwhile to move in response to even relatively small differences in state conditions.

13 The critical role of employment probabilities was first highlighted by Harris and Todaro (1970). 
terms of how changes in local labor market conditions affect them, reducing concerns that changes in labor market conditions impact education groups differently. This focus on early career workers also minimizes dynamic considerations, since the migration choices of older workers are likely determined by an array of the labor market shocks and employment outcomes they experienced over their careers as well as more complicated family and lifecycle considerations. ${ }^{14}$ Moreover, new labor force entrants are of interest because they are potentially vulnerable to scarring effects if early experiences have lasting effects on labor market outcomes. ${ }^{15}$

I focus on migration across state lines because this measure reflects movement between distinct local labor markets and has some advantages over a measure of mobility based on movement between smaller areas, like MSAs. ${ }^{16}$ At the state level, I am more likely to capture a general change in a local economy rather than changes in a more specific set of industries. Examining state-to-state migration also alleviates some concerns that different local price levels are important determinants of migration, since cost of living likely varies less across states than across localities within states.

Lastly, short run changes in state economic conditions are less likely than long run changes to influence educational attainment decisions. Short run changes are also less related to parental mobility decisions, allowing me to interpret the results as the effect of local conditions on individual migration decisions, rather than as the product of an intergenerational mobility process.

14 See Beaudry and DiNardo (1991) and Bartel (1979) on these issues. 15 A growing literature explores these effects: Ellwood (1982); Gardecki and Neumark (1998); Devereux (2002); Oreopolous (2002); and Kahn (2004).

16 A movement across state boundaries does not always constitute a significant change of location (some metropolitan areas spill across state borders), but differences in the share of workers migrating across state lines by education group are very similar to differences in the shares of workers migrating across any other meaningful approximation to a local labor market. For example, computations with CPS data show that the share of college graduates who move between counties over a five-year period is about twice as high as the share of non-graduates making that move. Along most measures of geographic mobility--e.g. moves between states over a 5 year period, moves out of birth state, etc.- college graduates are roughly twice as likely to make a given move as non-graduates. Mobility differentials between other education groups are similarly stable. 


\section{A. The Labor Demand Index and U.S. Census Microdata}

For my purposes, a measure of state labor market conditions that separates employment growth into increases in labor demand and increases in labor supply is superior to one that conflates the two. Increases in state labor demand correspond to labor market conditions favorable to new entrants, while increases in state labor supply may simply mean that new labor force entrants face more competition for jobs. Labor demand driven state employment growth should increase the likelihood that young workers locate there, but labor supply driven growth may deter them. A measure of state employment growth that isolated demand from supply was initially developed by Bartik (1991). Drawing on Bartik's instrument, I create a measure of state labor market conditions at the time an individual started work that I call the Labor Demand Index (LD Index). The LD Index measures deviations of demand-driven state employment growth from predicted state employment during the years a birth cohort was ages 18 to 22 . Specifically,

$$
L D \text { Index }_{\text {isbt }}=\left(\sum_{r=\text { year } 18}^{\text {year } 22}\left(d_{s r}-\tau_{s r}\right)\right) / 5
$$

where year 18 and year 22 are the years individual $i$ turned 18 and 22, respectively.

$d_{s r}=\sum_{k}\left[e m p_{s r-1} \cdot \Delta E M P_{k r}\right]$, where $e m p_{s r}$ equals state $s$ employment at time $r, E M P_{k r}$ equals national employment growth in industry $k$ year $r$, less state $s$ employment in $k$; and $\tau_{\text {sr }}$ is a state-specific time trend. Note that the LD Index for a given state is the same for all individuals born in a given year. I average state labor demand conditions over a worker's prime labor market entry years because state conditions may fluctuate considerably from year to year, and their effects on labor demand may persist beyond that year through knock-on effects (queues) and substitutability of workers across cohorts. Using the average also accounts somewhat for the fact that the year in which a worker enters the labor market is flexible. I also remove variation arising from long-run growth in particular sectors. This type of growth is captured by the state specific trends. 
Detrending results in variation that most closely resembles the local labor demand shocks described in Figure 2 and abstracts from migration in response to long-run state labor demand growth. The drawback to this procedure is that it means that the state labor supply response to a percentage point in my measure is not comparable to responses computed using non-detrended measures of labor demand.

A data set with annual state-level Bartik-style labor demand measures was generously provided by Raven Saks. Saks' computations were based on data on state-level employment used to compute LD Index are those published by the U.S. Bureau of Labor Statistics. I scale the LD Index so that all coefficients reflect the impact of an additional percentage point of demand driven state employment growth relative to trend over an individual's 18 to 22 years. Figure 3 plots variation in the LD Index for several birth states. The cyclical nature of the index is apparent, as is the fact that variation in the LD Index exists across states. Figure 3 includes results for the states that experience the largest and the smallest swings in the LD Index. Michigan experienced the largest swing, a change of 3.09 percentage points between natives born in 1960 and those born in 1966 . Wyoming experience the smallest change, 1.66 between natives born in 1970 and those born in 1975 .

I match the LD Index to individual-level Census microdata from the Integrated Public Use Micro Sample (hereafter IPUMS; Ruggles and Sobek, 2003) for the years 1980, 1990 and 2000. I divide individuals into four education groups: dropouts who have not completed a high school degree or GED; high school graduates and GEDs; some college, which consists of those with one to three years of some kind of post-secondary education; and college graduates, who have a bachelor's degree or higher. ${ }^{17}$ The sample drawn from each year consists of non-institutionalized

17 Individuals who have started but not yet completed college by the time I observe them in the Census will be grouped in the Some College category. It is likely that a number of future college graduates are in this group, as the age of college completion and prevalence of non-traditional college students have both increased over time (Turner, forthcoming). 
U.S. natives with non-imputed states of birth. ${ }^{18}$ The sample is restricted to those with hourly wages of more than one dollar and less than $\$ 100$ in constant dollars. ${ }^{19}$

Table 1 presents summary statistics for relevant variables from the IPUMS sample by Census year and age group. The birth year minimum and maximum is listed for each subsample as an aid to determining which birth cohorts are included in analyses using different age groups. The share of blacks and women is highly stable across cohorts and years in my sample. Consistent with well-known trends, the fraction Hispanic increases and the fraction currently married decreases in more recent cohorts. The decline in the fraction married is particularly pronounced among the 24 to 30-year-olds and likely reflects increases in the age at first marriage. The tendency to reside outside of birth states and regions increases slightly with age but is stable across cohorts. ${ }^{20}$ Finally, real wages are stable throughout my sample, and the LD Index is centered at zero as expected, although Table 2 shows that its variance fluctuates from cohort to cohort.

\section{B. The Conditional Logit Model}

To examine the responsiveness of education groups to state demand conditions, I estimate a conditional logit model of the individual choice problem represented in Equation 2. The data is expanded to $\mathrm{Nx} 50$, so an individual is potentially observed 50 times, once for each possible state of residence. The model can be summarized as follows:

$$
\text { Choice }_{i}=\Phi\left(L D \text { Index }_{b s} \cdot e d u c^{j}, X_{b s j}\right)
$$

where $i$ indexes individuals, $s$ indexes state, $b$ indexes year of birth, and $t$ indexes current year. Educ are dummy variables that indicate whether $i$ is a member of each of four education groups indexed by $j$. The dependent variable in this specification is a dummy called Choice, which equals 1 if an

18 According to IPUMS staff, observations requiring imputation of birth states were most likely a random subset. 19 This is to maintain a comparable sample across the analyses of mobility decisions and labor market outcomes. The results are not sensitive to including those with zero earnings in analyses of the mobility decisions.

20 This is consistent with lifecycle trends described in Greenwood (1997). 
individual resides in the designated state at the time I observe him in the Census data. The LD Index is matched 50 times, based on each of the potential states of residence and the individual's year of birth. The structure of the conditional logit model only allows for controls that vary across the possible choice states, although individual covariates are held constant due to the structure of the underlying conditional logit model. ${ }^{21}$ I describe the additional state level controls in this specification in more detail in Section IV.

One concern with the use of cross sectional data is that more and less educated individuals may be differentially likely to reside outside their state of birth prior to age 18. For example, more educated individuals tend to have more educated parents, who in turn may have moved their children out of their birth states. A more serious concern, and one that could also affect interpretation of the conditional logit results, is that more educated parents may move their children to better performing states. In this case, parental responsiveness to state labor market conditions would make it appear that their more educated offspring are more responsive to state conditions than other early career workers. In Appendix A, I provide empirical evidence that neither concern is supported by the data. I find that college graduates are somewhat more likely than high school graduates to reside outside their states of birth in their late teens, but the difference is small compared to the level of out of birth state residence among teenagers overall. ${ }^{22}$

I can also test whether educational attainment is predicted by the conditions summarized in

\footnotetext{
${ }^{21}$ See McFadden (1974) for a discussion of this. A possible alternative specification is the nested logit, for example as used in Knapp et al. (2001). The Census data I use here, combined with the large number of choices, make estimation of a nested logit model impractical. Moreover, it is unclear whether individuals make a migration decisions hierarchically, first whether to move or stay and then where to move conditional on choosing to do so. It seems equally likely that individuals decide whether and where to move jointly, e.g. should I move to Texas? Conditional logit models the latter. For more on this modeling decision and the computational challenges surrounding conditional logit, see Davies et al. (2001), Scott et al. (2005), and O’Keefe (2004).

${ }^{22}$ Using a previous version of my measure of early state labor market conditions, I also find that, as teenagers, college graduates are no more likely than high school graduates to reside in a state that will have better labor market conditions at the time they enter the labor force.
} 
the LD Index. ${ }^{23}$ I find no evidence that educational attainment for the 24 to 30 -year-old sample is predicted by the LD Index. To a lesser extent, I can also test whether the LD Index reflects shocks that are similar for all groups of workers. I have constructed education group specific versions of the LD Index designed to capture changes in state conditions that are potentially more relevant to one group or another. The indices calculated in this way were highly correlated with one another and produced similar results when substituted for the LD Index in the main estimations. This provides reasonable evidence that the LD Index measures economic conditions that affect the prospects of all education groups similarly.

\section{The Effects of State Labor Market Conditions on Residence Choices}

The leftmost column in Table 3 lists the main covariates included in the conditional logit estimations. Interactions of the LD Index with education allow education groups to differ in their responsiveness to state labor market conditions. Since high school graduates are the omitted category in all specifications, the level effect of LD Index represents the effect of state labor market conditions on the probability that an average high school graduate chooses to reside there. The remaining covariates control for underlying trends in state-to-state migration and for persistent state characteristics that affect migration. I account for any compositional differences in race or gender across education groups by including interactions of the LD Index with dummy variables for gender, race and Hispanic ethnicity in all specifications.

In the first specification, dummy variables control for whether the choice state is the individual's birth state or in his birth division. ${ }^{24}$ Subsequent specifications capture the effect of birth state using a more flexible measure for long-term state-to-state migration flows that vary by birth year and birth state. If a choice state is an individual's birth state, then the flow equals the share of 
31-35 year old state natives who reside there at the time of the Census. Otherwise, it equals the share of birth state migrants who reside in the choice state. I also construct an education-specific flow variable to capture differences in long-term flows across education groups. These flows capture long-term trends such as migration to the South and to the coasts. More importantly, they capture the numerous other important but less obvious state-to-state migration trends. ${ }^{25}$

Other controls capture permanent state characteristics. All specifications control for the distance between the choice state and birth state measured as hundreds of miles between the two state capitals. Specifications [1]-[4] include the log of average annual income in the choice state for an individual's education group to control for differences in long-term earnings levels across states. ${ }^{26}$ Specification [4] also includes a dummy variable for coastal states. The final specification includes state fixed effects to capture particular state effects more flexibly.

Results from estimation of the conditional logit model are presented in Table 3. The top numbers in each cell are odds ratios implied by the estimated coefficients, which are given below the odds ratios. Standard errors are in brackets. ${ }^{27}$ For ease of interpretation, I discuss the results in terms of the odds ratios implied by the coefficients rather than the coefficients themselves.

Odds ratios in the top row of Table 3 show that increased state labor demand early in his career increases the likelihood that the average 24-30 year old high school graduate resides in a state. Estimates of the level effect of the LD Index range from 1.09 to 1.21. In other words, an additional

25 For more on these and their great variety, see U.S. Census Bureau (2003) and Foote and Kahn (2000). Davies et al. (2001) examines the role of some of these fixed state factors in state to state migration.

26 Average annual income by state and education group was computed by taking the mean of total wage and salary income conditional on state of residence and education group in the sample of 31-35-year-old workers from the Census. I matched the average of this measure of long-term income to the Nx50 data set of 24 to 30 year olds on choice state and education group. The log of this average was entered as the dependent variable to capture long-run earnings that an individual might expect, rather than the earnings he actually experienced. In the matched sample of 24 to 30 year olds, $\log$ average annual income has a mean of 9.4 and a standard deviation of 0.31 . Thus a one unit change in this variable represents a large jump, approximately three standard deviations, in an education group's long-term earnings at the state level. Consistent with this, workers are 13 to 25 times more likely to reside in a state with a long-term income measure one unit higher than another state's.

27 Odds ratio $=[\operatorname{pr}($ leave birth state $) / \operatorname{pr}($ stay $) \mid \operatorname{LD}$ Index $=x] /[\operatorname{pr}($ leave birth state $) / \operatorname{pr}($ stay $) \mid$ LD Index $=x-1]$. Note that an odds ratio equal to one indicates that the dependent variable has no effect on an individual's odds of choosing a state. 
percentage point of demand driven employment growth increases the odds that a high school graduate chooses a state by approximately $9-21 \%$.

The odds ratios on the interactions of the LD Index with dummies for some college education and for a college degree are also greater than one. Since odds ratios are multiplicative rather than additive, these results show that individuals with some college education are more sensitive to early career state labor market conditions than high school graduates. A unit change in the LD Index improves the odds that the average college educated individual chooses a state by 10$44 \%$ more than it improves those odds for high school graduates, or by $34-57 \%$ overall. $^{28}$

These results are little affected by additional controls included in the estimation, particularly across specifications [1]-[4]. Odds ratios on the additional controls are in the expected direction and show that the long-term trends in migration and persistent differences across states are important determinants of migration, but the differential response of education groups to state economic conditions is robust to these controls. It is striking that differentials, both between high school and college graduates and between college graduates and workers with some college, are most pronounced when state fixed effects are included in specification [5]. This is potentially due to the fact that this specification does the best job of controlling for the complicated, long-term sorting by skill patterns examined by Dahl (2002).

Are these responses large or small? On the face of it, a 57\% increase in the odds that a college graduate chooses a state certainly seems large, but assessing the magnitude of these requires that odds ratios first be converted into probabilities. ${ }^{29}$ This exercise reveals that a unit change in the LD Index increases the probability that a college graduate chooses a state by $6.3-11.1 \%$ at the

28 For example, in [1], the total effect of a unit change in the LD Index on the odds that a college grad chooses a state equals $1.21 \times 1.11$.

${ }_{29}^{2}$ Also note that a one unit change in the LD Index reflects a movement of more than two standard deviations in most years of the data. 
mean. ${ }^{30}$ For high school graduates, the effect is only $1.9-3.1 \%$. Thus college graduates are approximately two to five times more responsive to state labor market conditions than are high school graduates. From Table 2, it is obvious that a one unit change in the LD index is a large one, but it is the education group difference in responsiveness that is the parameter of interest. By this metric, college graduates are at least twice as likely to change their behavior in response to a given set of labor demand conditions. Thus, the difference in responsiveness across education groups is substantial. $^{31}$

\section{Does the Response to Local Conditions Affect Labor Market Outcomes?}

A second way to assess the magnitude of the responses of high school and college graduates to early state labor market conditions is to ask whether the flows implied by Table 3 are sufficient to arbitrage the wage effects of state labor demand shocks. In the labor market clearing model depicted in Figure 2, workers move between labor markets following heterogeneous labor demand shocks in order to capture the highest wage available for their skills. In Table 4, I test whether conditions in a worker's birth state at the time he entered the labor market are a significant determinant of his wages 4-10 years later, when I observe him in the Census data. If migration flows among workers in their early twenties are large enough to arbitrage the wage effects of state labor demand shocks, then wages for workers in their late twenties should be unaffected by the labor demand shocks to which they were likely exposed early in their careers.

Table 4 estimates log wage equations in which the LD Index in a worker's birth state is allowed to influence the wages he earns in his late twenties. For the average worker, labor market

30 This is a conventional approximation of the probability effect implied by odds ratios. Alternative estimates of the probability could be computed at other points in the distribution of the migration variables. Forty-five percent of college graduates reside outside their birth states as compared to twenty-five percent of high school graduates. The odds that the average college graduate leaves his birth state are twice those of the average high school graduate.

31 The relative difference is similar in magnitude to that implied by estimates in Bound and Holzer (2000). However, due to differences in the way they calculate their measure of local labor demand conditions, the levels of the responses are not directly comparable. 
conditions in an individual's birth state at the time he starts work do not predict the wages he earns in his late twenties. However, the interactions of the LD Index with education dummies show that this average estimate in Column 1 masks significant effects for high school graduates. Interestingly, workers with only one to three years of college are no more insulated from these conditions than high school graduates. The coefficients in Column 1 imply that a unit change in the LD Index leads to wage increases of approximately $5 \%$ for high school graduates and those with some college. ${ }^{32}$ The wages of college graduates, on the other hand, show no effect of early labor market conditions in their birth states by the time they reach their late twenties. The third column shows that even among college graduates who continue to reside in their birth states into their late twenties, early conditions have no discernible wage effect.

Are the mobility differences across education groups documented in Table 3 sufficient to explain this pattern of wage effects? Given conventional estimates of the elasticity of substitution between skilled and unskilled workers, the answer is yes. A percentage point increase in state labor demand relative to trend leads to a 4\% decline in relative wages for college graduates and a 4-8\% increase in their relative labor supply. These numbers imply elasticities of substitution between 1 and 2, which agree with published estimates. ${ }^{33}$ The final two columns of Table 4 present results consistent with this exercise. Wage equation estimates in the fourth column show that regardless of educational attainment, individuals who move out of their birth states do not experience the wage effects of birth state shocks (at least by their late twenties). Instead, high school graduates who move experience wage effects associated with their destination state labor market. Consistent with the relative wage effects in columns 1 and 2 of Table 4, the wage effects of destination state conditions have been arbitraged away for college graduates.

32 These medium-term levels of persistence are consistent with evidence in Guvenen (2004) and Ziliak et al (1999). I would like to observe the year-by-year pattern, but estimates of the effect of the LD Index on single-year age groups are too noisy to distinguish a real pattern, particularly different patterns for more and less educated workers.

33 Hamermesh (1993), pp. 105-110. 
Alternative explanations for these results that do not rely on simple supply and demand forces are possible but seem unlikely. Perhaps college graduates are simply shielded from the effects of local conditions generally or perhaps the effects of lagged conditions dissipate more quickly for them than for less educated workers. However, these explanations do not explain the greater responsiveness of college graduates' location decisions to early labor market conditions. ${ }^{34}$ An alternative that explains both Table 3 and 4 results would require location preferences to differ across education groups systematically with labor demand conditions. For example, the migration response of college graduates to local labor market conditions may reflect preferences for high demand areas, perhaps because they have low crime or other social amenities.

\section{Explaining Educational Differences in Migration Responses}

Thus far, the empirical specifications in this paper do not examine the role that changes in national conditions play in migration decisions (although the level effect of these is held constant in the conditional logit). In the final set of results, I introduce additional measures to contrast the importance of changes in the level of national employment with changes in the dispersion of state labor market conditions for worker migration decisions. Greater spatial variation in labor demand shocks across states corresponds to greater potential gains from moving. Changes in the level of economic conditions that apply to all markets do not affect potential gains from moving, but they do reflect changes in the average probability of employment across the country—something which may be more important to less educated workers seeking jobs in a new location than to college

\footnotetext{
34 Another possibility is that movers are of higher ability than non-movers. This unobservable trait may increase their propensity to move and insulate them from negative wage shocks. However, Hunt (2004) finds most migrants are not of higher ability than non-migrants. Only individuals who move across markets while maintaining employment with the same firm show higher ability than comparable non-movers. Same-employer movers are not likely an important group of migrants for the age ranges I consider. Moreover, this story cannot account for the fact that non-mover college graduates are also insulated from state labor demand shocks in Table 4.
} 
graduates. ${ }^{35}$ As was explained in Section II, examining education group responses to different degrees of spatial variation in state conditions will allow me to distinguish between three major theories of educational differences in the response to state labor demand shocks. Holding national employment growth conditions constant will help control for changes in the average worker's probability of employment.

To proxy for spatial variation in labor demand conditions, I compute the variance of the LD Index for each birth year cohort. To proxy for national conditions generally, I reconstruct the LD Index using deviations of national employment from trend as the base. ${ }^{36}$ Both measures are somewhat hard to interpret, so I convert them to dummy variables equal to 1 if a birth year cohort experienced above-median (high) national employment growth early in their careers or abovemedian (high) spatial variation in early career state demand conditions. In order to include these measures in the clogit specification from Table 3, I interact each of them with the choice state's LD Index. Thus, the coefficients show how high national growth and high variation in state conditions affect the attractiveness of states with particular labor demand conditions. The results are shown in Table 5.

Table 5 gives a subset of implied odds ratios from estimation of a single conditional logit model. The remaining covariates (not shown) are the same as those in specification [5] of Table 3. The first row of Table 5 shows the effects of state labor demand conditions on the average high school graduate's choice under various conditions in the national labor market. The leftmost column shows that holding national conditions constant increases the estimated responsiveness of high school graduates to state labor demand conditions from an odds ratio of about 1.2 to 1.7. That

\footnotetext{
35 Basker (2002) finds that less educated workers are much less likely to move with a job offer at the destination in hand. Rather, these workers typically move to an area, then search for jobs.

36 Shocks to national employment are the residuals from a population weighted regression of log national employment on the time trend. As with the LD Index, the average deviations are scaled by 100, so a unit change in the national LD Index represents an additional percentage point of national employment growth on average over the years an individual was 18 to 22 years of age.
} 
is, a unit change in the LD Index increases the odds that a high school graduate chooses that state by $70 \%$, an effect that exceeds even the highest estimated effect for college graduates in Table 3 . The second and third columns show that the responsiveness of high school graduates to a given state's early labor market conditions is amplified in times of high national employment growth (booms) but is dramatically reduced in times of high spatial variation in conditions, respectively. The bottom row of Table 5 shows that the effects for college graduates are nearly the opposite of those for high school graduates. Once national business cycle conditions and spatial variation in demand shocks are accounted for, the location choices of college graduates are no longer sensitive to a state's demand shocks generally and this holds regardless of the level of national employment growth. The third column shows that college graduates are particularly attracted to booming states in times when spatial variation in demand shocks is high. These are precisely the times when location choices must be most responsive state conditions in order to fully arbitrage wage effects of local demand shocks.

Section II described a simple test to distinguish three competing theories about why more and less educated workers might differ in their responsiveness to spatial variation in labor demand. The test rests on the fact that the three theories all have different implications about the degree of wage arbitrage achieved by cohorts exposed to different degrees of spatial variation in labor demand conditions. This test is summarized is Table 6 , but the results in Table 5 already hint at the conclusion. The Table 5 estimates show that the location choices of high school graduates can in fact be highly responsive to state labor demand conditions but only when variation in labor demand conditions is low and national employment growth generally is good. They are capable of making wage arbitraging moves, but only when their own current wages are not too low and when their average probability of employment is high. College graduates, on the other hand, are more likely to 
make arbitraging moves when they are most necessary: when the potential gains from moving are highest due to greater spatial variation in labor demand conditions.

Estimates of wage convergence in Table 7 support this conclusion and provide evidence strongly in favor of a credit constraints theory of educational differentials in arbitrage migration. To

obtain the estimates in Table 7 , I first regressed log hourly wages on the same set of covariates used in the Table 4 wage equations with the exception of birth state labor demand conditions. I then regressed the residuals from this wage equation on birth state demand conditions separately by educational attainment and one or both of the national conditions measures. The numbers in each cell of Table 7 are coefficients on the birth state LD Index in a regression conditioned on the educational group in the left column and the national conditions measure(s). Standard errors clustered on birth state and birth year are shown in brackets.

The top panel of Table 7 shows that birth state LD conditions have medium term wage effects for high school graduates only among cohorts that experienced high spatial variation in labor demand shocks. Among other cohorts of high school graduates and among college graduates, the wage effects of these birth state conditions have been arbitraged away by the time they reach their late twenties. The bottom panel shows that the lack of wage convergence among these cohorts is driven by cohorts who also experienced low levels of national employment growth. Thus the test results match the implications of the credit constraint theory and reject theories of differences in educational resposiveness due to poor information or lower net gains among the less educated.

\section{Conclusion}

This paper asks whether the highly educated are better at moving across labor markets within the U.S. to take advantage of spatial variation in wage levels and employment conditions. I answer this question empirically by estimating the effects of early career local labor market 
conditions on subsequent residential location choices and labor market outcomes for different education groups. I use a measure of labor market conditions that captures shocks to state labor demand during a birth cohort's years of peak labor market entry.

Estimates using U.S. Census of Population microdata from 1980 to 2000 show that workers in their late twenties are more likely to reside in states that experienced high labor demand during the years these workers most likely entered the market. However, the residential location choices of college-educated workers are much more sensitive to these early state conditions than are those of high school graduates or dropouts. An increase in state labor demand of one percentage point during a cohort's labor market entry years increases the probability that high school graduates reside in the state by $2-3 \%$ while the effect for college graduates is several times greater, in the range of 6 $11 \%$. Cross-state migration by college graduates fully equalizes the wage impact of early career labor demand shocks in their home states, but the same is not true for less educated workers. This lack of wage convergence is most severe for less educated workers who entered the labor market during periods of high spatial variation in state conditions and low national employment growth. These results are consistent with theories of educational differences in migration that assume less educated workers are credit constrained and therefore unable to finance a move when their incomes are particularly low. A simple policy intervention that subsidizes long-distance moves for low earners in states with low labor demand could significantly improve the spatial allocation of low skilled workers in the U.S.. 


\section{References}

Bartel, Ann P. “The Migration Decision: What Role Does Job Mobility Play?” American Economic Review. 69(December 1979): 775-786.

Bartik, Timothy. Who Benefits from State and Local Economic Development Policies? Kalamazoo, Michigan: W.E. Upjohn Institute for Employment Research (1991).

Basker, Emek. "Education, Job Search and Migration.” University of Missouri - Columbia. Mimeo (September 2002).

Beaudry, Paul, and Dinardo, John. "The Effect of Implicit Contracts on the Movement of Wages Over the Business Cycle: Evidence From Micro Data.” Journal of Political Economy. 99(1991): 665-688.

Blanchard, Olivier, and Katz, Lawrence. "Regional Evolutions." Brookings Papers on Economic Activity. 1992(1992): 1-61.

Borjas, George. "Does Immigration Grease the Wheels of the Labor Market?" Brookings Papers on Economic Activity. 1(2001): 69-133.

Borjas, George. "Native Internal Migration and the Labor Market Impact of Immigration." Manuscript. Harvard University (2004).

Borjas, George J.; Freeman, Richard B.; and Katz, Lawrence F. "Searching for the Effect of Immigration on the Labor Market." American Economic Review. 86(1996): 246-251.

Bound, John and Holzer, Harry J. "Demand Shifts, Population Adjustments, and Labor Market Outcomes during the 1980s." Journal of Labor Economics. 18(2000): 20-53.

Cameron, Stephen V. and Taber, Christopher. "Estimation of Educational Borrowing Constraints Using Returns to Schooling.” Journal of Political Economy. 112(2004):132-182.

Card, David and Lemieux, Thomas. "Dropout and Enrollment Trends in the Post War Period." Risky Behavior among Youths: An Economic Analysis. Jonathan Gruber, ed. Chicago: University of Chicago Press (2001).

Decression, Jorg, and Fatas, Antonio. "Regional Labor Market Dynamics in Europe." European Economic Review. 39(1995):1627-1655.

Dahl, Gordon B. "Mobility and the Return to Education: Testing a Roy Model with Multiple Markets." Econometrica. 70(2002): 2367-2420.

Davies, Paul S., Michael J. Greenwood, and Haizheng Li. "A Conditional Logit Approach to State to State Migration." Journal of Regional Science, 41(2001): 337-360. 
Devereux, Paul J. “The Importance of Obtaining a High Paying Job.” Manuscript. California: UCLA (2002).

Eichengreen, Barry. "Thinking about Migration: Notes on European Migration at the Dawn of the Next Millenium." University of California at Berkeley Working Paper in Economics C93-019 (1993).

Ellwood, David T. “Teenage Unemployment: Permanent Scars or Temporary Blemishes?” The Youth Labor Market Problem: Its Nature, Causes, and Consequences. Richard B. Freeman and David A. Wise, eds. Chicago: University of Chicago Press: 1982.

Foote, Christopher and Kahn, Matthew. "Are Recessions Reallocations? Evidence from the Migration of U.S. Taxpayers, 1975-1998.” Tufts University, Mimeo (December 2003).

Gardecki, Rosella and Neumark, David. "Order from Chaos? The Effects of Early Labor Market Experiences on Adult Labor Market Outcomes." Industrial and Labor Relations Review. 59(1998): 299-322.

Glaeser, Edward L. and Gyourko, Joseph. "Urban Decline and Durable Housing." NBER Working Paper \#8595 (2001).

Greenwood, Michael J. "Research on Internal Migration in the United States: A Survey." Journal of Economic Literature. 13(1975): 397-433.

Greenwood, Michael J. "Internal Migration in Developed Countries.” Handbook of Population and Family Economics. Mark R. Rosenzweig and Oded Stark, eds. New York: Elsevier Science: 1997.

Guvenen, Fatih. "Learning Your Earning: Are Labor Income Shocks Really Very Persistent?" University of Rochester, Mimeo (August 2004).

Hamermesh, Daniel S. Labor Demand. Princeton, NJ: Princeton University Press: 1993.

Hanson, Gordon and Slaughter, Matthew. "The Rybczynski Theorem, Factor Price, Equalization, and Immigration: Evidence From U.S. States.” NBER Working Paper \#7074 (1999).

Harris, John R. and Michael P. Todaro. "Migration, Unemployment and Development: A TwoSector Analysis." American Economic Review 60(1970): 126-142.

Hunt, Jennifer. “Are Migrants More Skilled Than Non-Migrants? Repeat, Return and SameEmployer Migrants.” NBER Working Paper \#10633 (2004).

Kahn, Lisa Blau. "The Labor Market Consequences of Graduating College in a Bad Economy." Manuscript. Chicago: University of Chicago (2003).

Kane, Thomas J. "College Entry by Blacks since the 1970's: The Role of College Costs, Family Background, and the Returns to Education." Journal of Political Economy. 102(1994): 878-911. 
Katz, Lawrence F. and Autor, David H. "Changes in the Wage Structure and Earnings Inequality." Handbook of Labor Economics, Volume 3. Orley Ashenfelter and David Card, eds. Elsevier Science B.V.: 1999.

Knapp, Thomas A., White, Nancy E. and Clark, David E. “A Nested Logit Approach to Household Mobility.” Journal of Regional Science. 41(2001): 1-22.

Lewis, Ethan. "Local, Open Economies Within the U.S.: How Do Industries Respond to Immigration?" Manuscript. Stanford University (2003).

Lkhagvasuren, Damba. "Big Locational Differences in Unemployment Despite High Labor Mobility." Manuscript, University of Rochester (2005).

McFadden, Daniel. “Analysis of Qualitative Choice Behavior.” Frontiers in Econometrics. Paul Zarembka, ed. New York: Academic Press (1974).

O’Keefe, Suzanne. "Locational Choice of AFDC Recipients within California: A Conditional Logit Analysis." Journal of Public Economics, 88(2004): 1521-1542.

Oreopolous, Philip. "The Long-Run Consequences of Living in a Poor Neighborhood." Manuscript. Toronto, Canada: University of Toronto (2002).

Puhani, Patrick A. "Labour Mobility - An Adjustment Mechanism in Euroland?” Forschungsinstitut zur Zukunft der Arbeit (IZA). Discussion Paper \#34 (March 1999).

Ruggles, Steven and Sobek, Matthew et. Al. Integrated Public Use of Microdata Series: Version 3.0. Minneapolis: Historical Census Projects, University of Minnesota, 2003. URL: http://www.ipums.org.

Schultz, Theodore W. "Investment in Human Capital.” American Economic Review. 51(1961):1-17.

Scott, Darren M. and Paul A. Coomes and Alexei I. Izyumov. "The Location Choice of Employment-Based Immigrants among U.S. Metro Areas.” Journal of Regional Science, 45(2005): 113-145.

Stevenson, Betsey. "The Internet, Job Search, and Worker Mobility." Manuscript. (November 2003).

Topel, Robert H. “Local Labor Markets.” Journal of Political Economy. 94(1986): S111-S143.

Turner, Sarah. "Going to college and finishing college: Explaining different educational outcomes." College Decisions: How Students Actually Make Them and How They Could. C. Hoxby, Ed. University of Chicago Press for NBER (forthcoming).

U.S. Census Bureau. "State-to-State Migration Flows: 1995 to 2000.” Census 2000 Special Reports. (August 2003).

URL: http://www.census.gov/population/www/cen2000/migration.html. 
von Wachter, Till M. "In the Right Place at the Wrong Time: The Role of Firms and Luck in Young Workers' Careers.” Manuscript. New York, NY: Columbia University (2002).

Ziliak, James P., Beth A. Wilson, and Joe A. Stone. "Spatial Dynamics and Heterogeneity in the Cyclicality of Real Wages." Review of Economics and Statistics, 81(May 1999): 227-236. 


\section{Appendix A: Sources of Measurement Error}

One concern with assessing responses to conditions in an individual's birth state is that more educated individuals tend to have more educated parents. More educated parents may have moved their children out of their birth states, leading to more measurement error in measuring birth state conditions to which more educated workers were exposed. A more serious concern, and one that also could affect interpretation of the conditional logit results, is that more educated parents may move their children to better performing states.

To check the severity of the first problem, I use Census data and the National Longitudinal Survey of Youth (NLSY 1979) to compare shares of college graduates and high school graduates residing outside their birth states at various ages. I proxy for an individual's future educational attainment with his parents' education in the Census data. I know future educational attainment, since I observe individuals annually from their late teens to their early thirties in the NLSY.

Figure A1 plots the shares of individuals residing outside their birth states at various ages. The NLSY results indicate that shares of individuals living outside their birth states during their late teens are roughly similar across future education groups. The average shares for 15 to 17 -year old high school graduates and college graduates were $20 \%$ and $24 \%$, respectively. The difference was statistically significant, but given the high level of measurement error these shares imply for both education groups, the difference is not likely to be economically significant. Using parental education to proxy for a child's future educational attainment in the Census data indicates bigger differences, but the close match of NLSY shares with Census shares for older individuals indicates that the NLSY shares for teenagers are believable. The NLSY shares appear to be a good approximation of the true levels of birth state residence in the Census data and any differential measurement error across education groups from this source is likely small.

The Census data also allow me to test the second source of potential bias: the possibility that more educated parents move their children to better state labor markets, and thus that it is parental responsiveness that leads more educated workers to locate in better state markets. Using a sample of 15 to 17-year-olds from the Census, I tested whether the children of college graduates would experience higher values of the EG Index in their states of residence during the years they would be 18 to 22 than would their high school graduate peers. I found no significant difference across groups in these "future" values of EG Index. I conclude that more educated parents are not moving disproportionately to states that will have a high value of the EG Index when their children enter the labor market. 


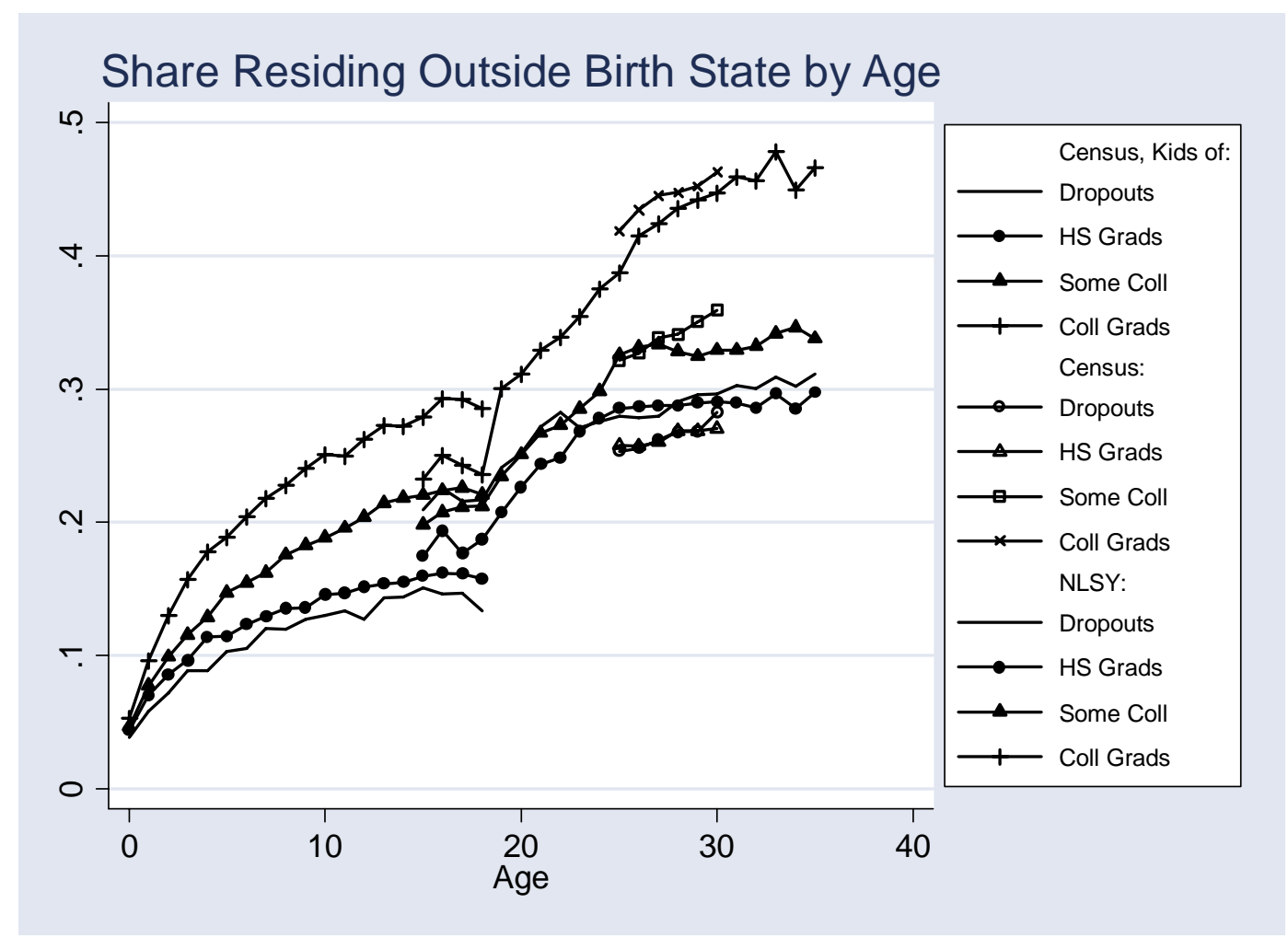

Figure A1: Share residing outside birth state by age. Groups represented are children of four education groups, aged 1 to 18 (from U.S Census data); four education groups, aged 14 to 30 (from NLSY); and four education groups, aged 24 to 35 (from U.S. Census). 


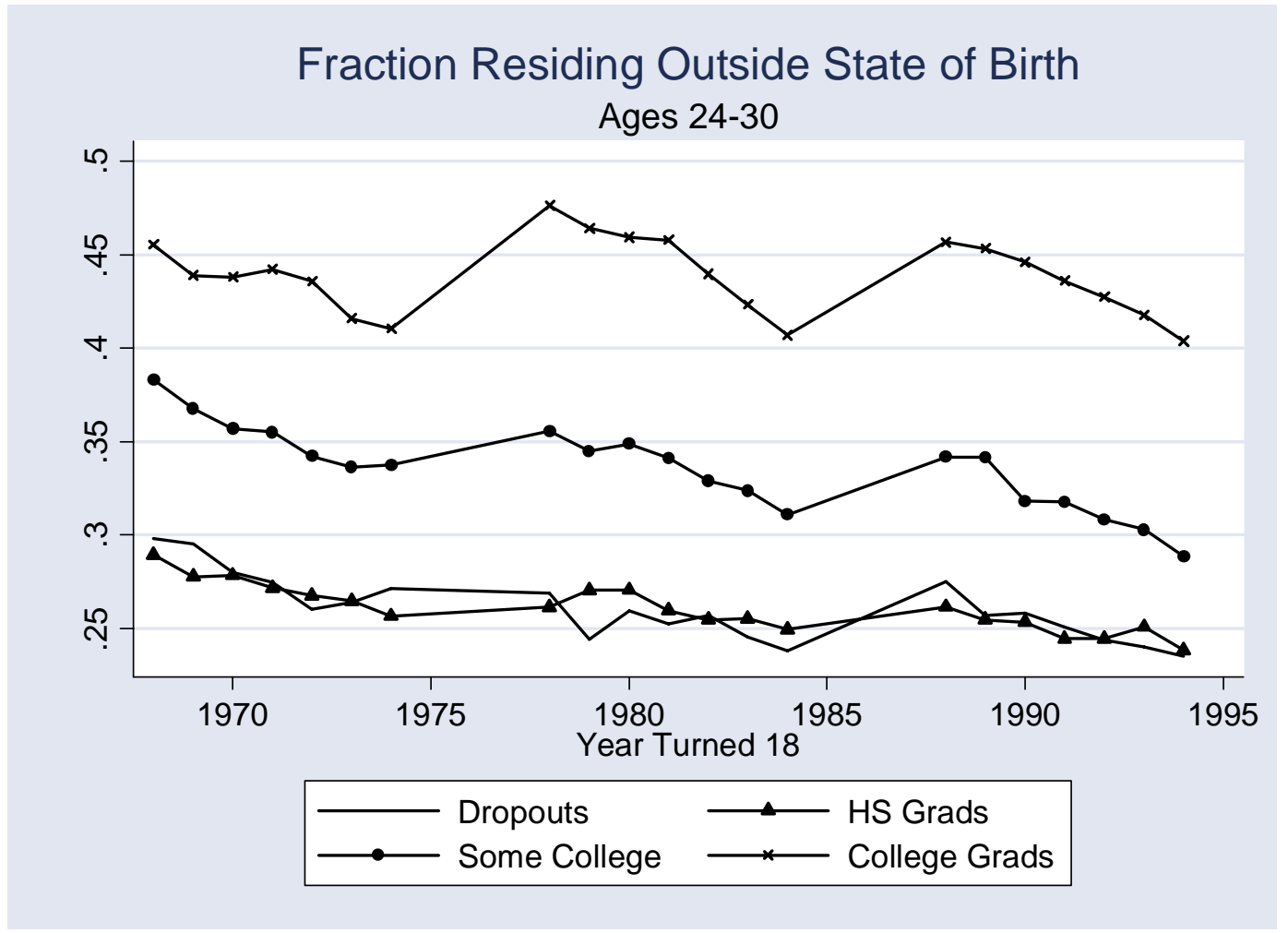

Figure 1 
Figure 2: Wage and Labor Supply Responses to a Labor Demand

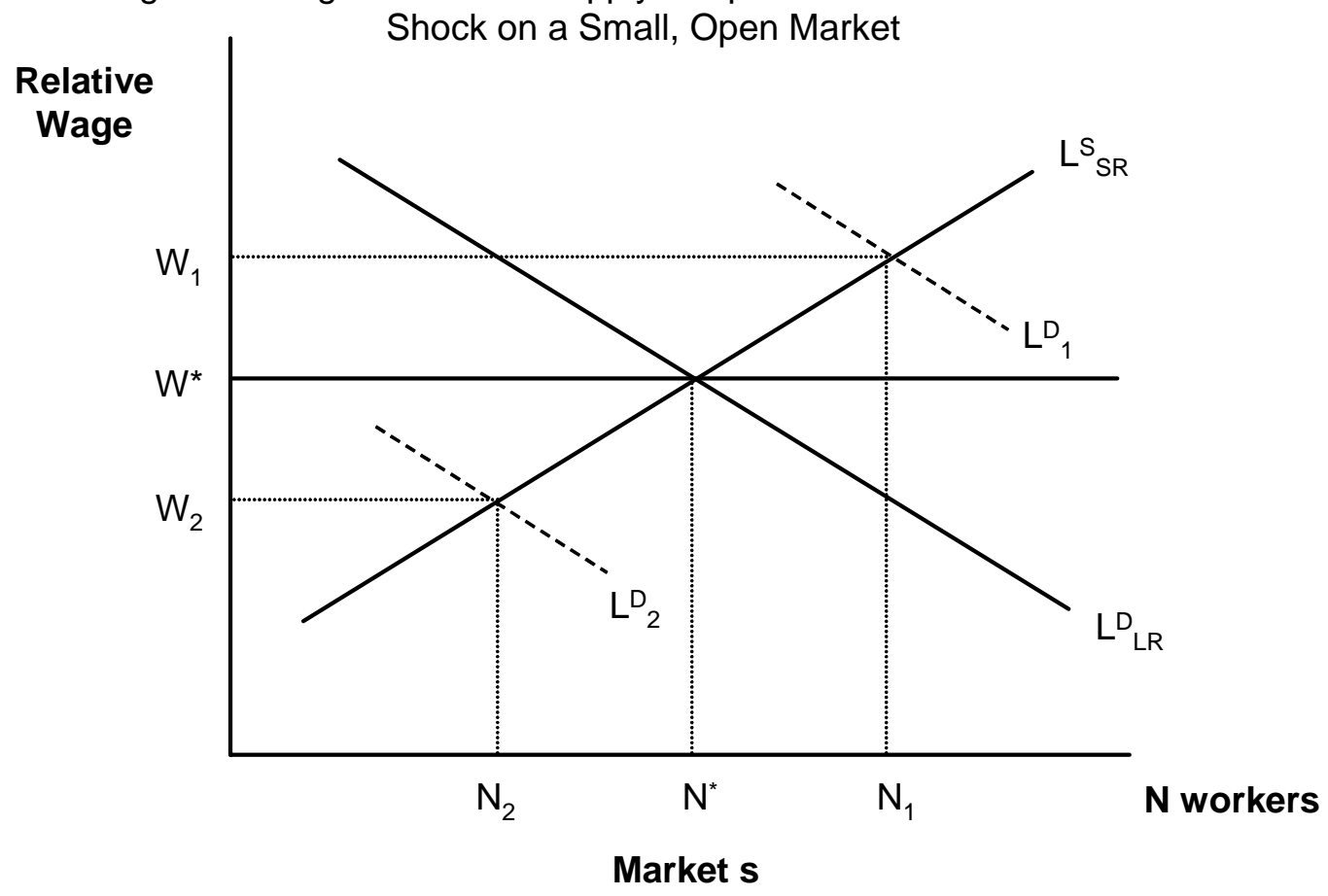




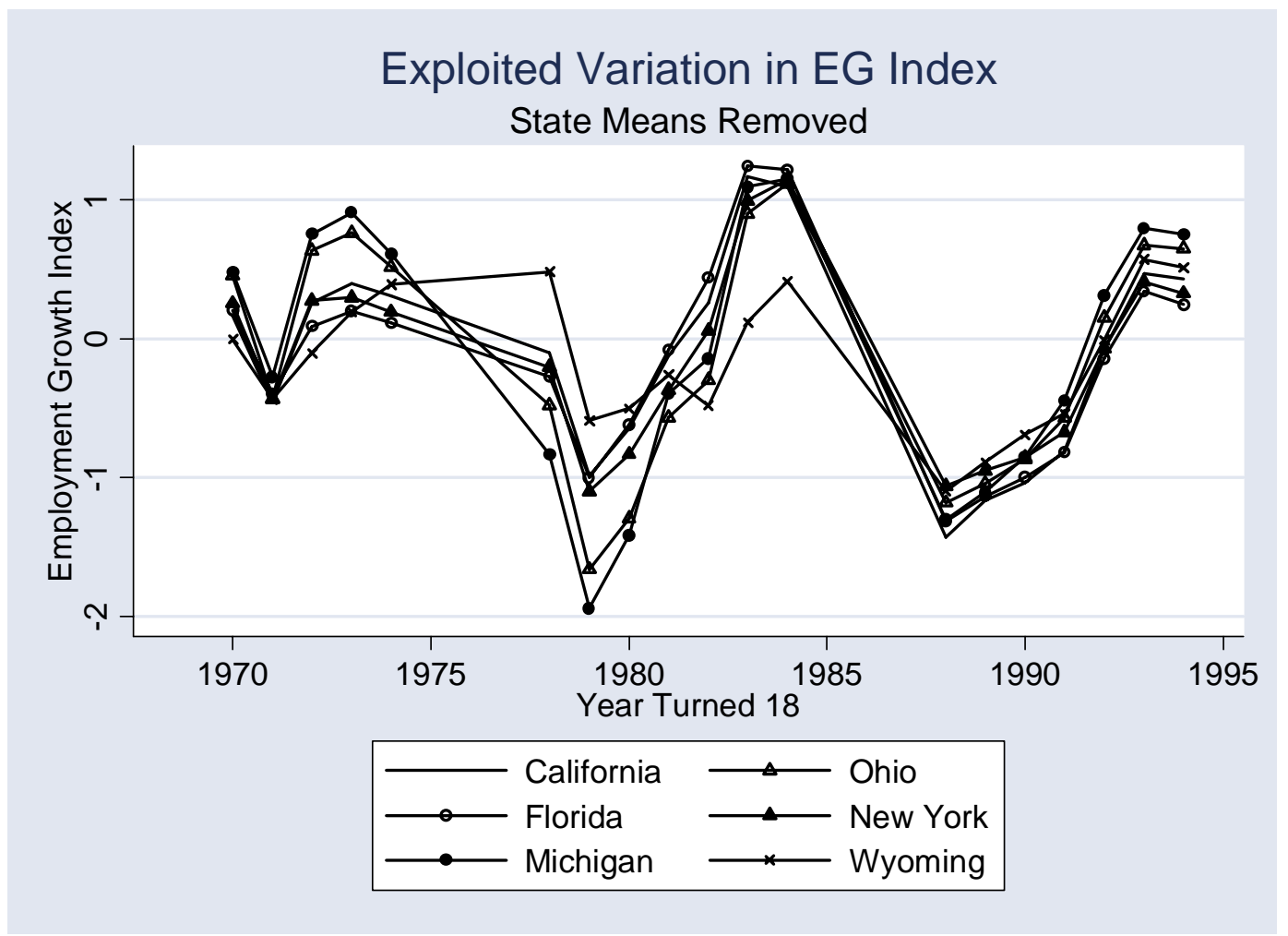

Figure 3 
Table 1: Variable Means for IPUMS 24-30 Year Olds

\begin{tabular}{|c|c|c|c|}
\hline Census Year: & 1980 & 1990 & 2000 \\
\hline Birth year min & 1950 & 1960 & 1970 \\
\hline Birth year max & 1956 & 1966 & 1976 \\
\hline \multicolumn{4}{|l|}{ Percent: } \\
\hline Female & 0.46 & 0.48 & 0.50 \\
\hline Black & 0.11 & 0.09 & 0.11 \\
\hline Hispanic & 0.04 & 0.05 & 0.08 \\
\hline Married & 0.61 & 0.54 & 0.48 \\
\hline Less than High School & 0.11 & 0.08 & 0.06 \\
\hline High School Graduate & 0.35 & 0.36 & 0.29 \\
\hline Some College & 0.29 & 0.33 & 0.35 \\
\hline College Graduate & 0.25 & 0.23 & 0.29 \\
\hline Moved out of Birth State & 0.34 & 0.33 & 0.33 \\
\hline Moved out of Birth Region & 0.26 & 0.25 & 0.24 \\
\hline Hourly Wage & $\begin{array}{c}7.82 \\
{[5.86]}\end{array}$ & $\begin{array}{c}7.53 \\
{[5.33]}\end{array}$ & $\begin{array}{c}7.96 \\
{[6.14]}\end{array}$ \\
\hline Log hourly Wage & $\begin{array}{c}1.89 \\
{[0.56]}\end{array}$ & $\begin{array}{c}1.85 \\
{[0.57]}\end{array}$ & $\begin{array}{c}1.90 \\
{[0.57]}\end{array}$ \\
\hline Labor Demand Index & $\begin{array}{l}0.197 \\
{[0.37]}\end{array}$ & $\begin{array}{c}-0.135 \\
{[0.83]}\end{array}$ & $\begin{array}{c}-0.463 \\
{[0.66]}\end{array}$ \\
\hline Observations & 181220 & 188226 & 156217 \\
\hline
\end{tabular}

Notes: Data from 1980, 1990, and 2000 IPUMS. Labor demand index data are from Raven Saks. Sample is non-institutionalized native wage earners. Index construction is described in text. 


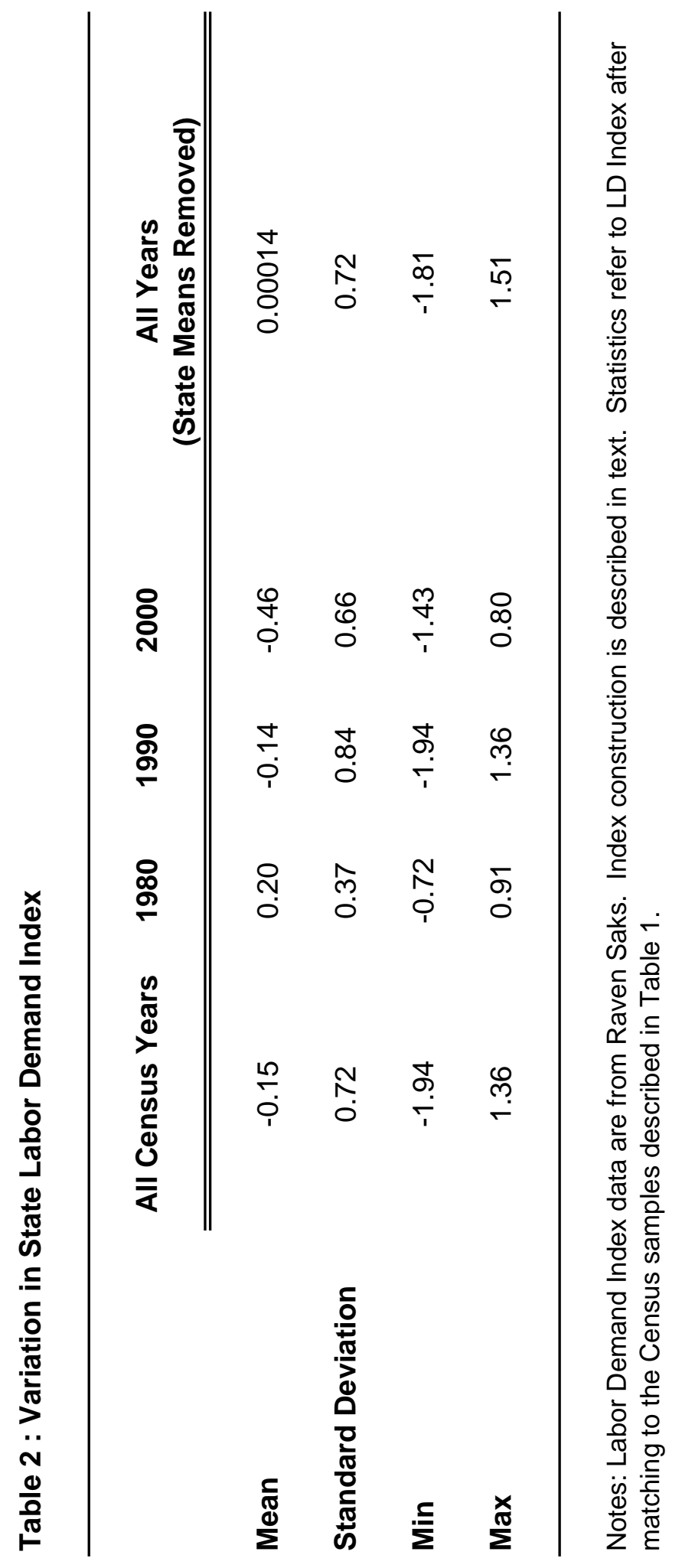


Table 3: Mobility Response to Early Labor Market Conditions

\begin{tabular}{|c|c|c|c|c|c|}
\hline \multicolumn{4}{|c|}{ Conditional Logit State of Residence Choice Model } & [4] & [5] \\
\hline LD Index & $\begin{array}{c}1.21 \\
0.193 \\
{[0.0210]}\end{array}$ & $\begin{array}{c}1.20 \\
0.180 \\
{[0.0208]}\end{array}$ & $\begin{array}{c}1.16 \\
0.149 \\
{[0.0190]}\end{array}$ & $\begin{array}{c}1.12 \\
0.12 \\
{[0.0191]}\end{array}$ & $\begin{array}{c}1.09 \\
0.09 \\
{[0.0194]}\end{array}$ \\
\hline LD Index x Dropout & $\begin{array}{c}0.962 \\
-0.0392 \\
{[0.0394]}\end{array}$ & $\begin{array}{c}0.969 \\
-0.0320 \\
{[0.0385]}\end{array}$ & $\begin{array}{c}0.965 \\
-0.0354 \\
{[0.0351]}\end{array}$ & $\begin{array}{c}0.98 \\
-0.02 \\
{[0.0357]}\end{array}$ & $\begin{array}{c}0.97 \\
-0.03 \\
{[0.0373]}\end{array}$ \\
\hline LD Index x Some College & $\begin{array}{c}1.08 \\
0.0763 \\
{[0.0263]}\end{array}$ & $\begin{array}{c}1.08 \\
0.0783 \\
{[0.0261]}\end{array}$ & $\begin{array}{c}1.12 \\
0.117 \\
{[0.0247]}\end{array}$ & $\begin{array}{c}1.14 \\
0.14 \\
{[0.0249]}\end{array}$ & $\begin{array}{c}1.17 \\
0.16 \\
{[0.0254]}\end{array}$ \\
\hline LD Index x College & $\begin{array}{c}1.11 \\
0.106 \\
{[0.0291]}\end{array}$ & $\begin{array}{c}1.10 \\
0.0985 \\
{[0.0290]}\end{array}$ & $\begin{array}{c}1.30 \\
0.259 \\
{[0.0323]}\end{array}$ & $\begin{array}{c}1.35 \\
0.30 \\
{[0.0323]}\end{array}$ & $\begin{array}{c}1.44 \\
0.36 \\
{[0.0324]}\end{array}$ \\
\hline Distance from Birth State & $\begin{array}{c}0.966 \\
-0.0349 \\
{[0.000502]}\end{array}$ & $\begin{array}{c}0.951 \\
-0.0499 \\
{[0.000511]}\end{array}$ & $\begin{array}{c}0.935 \\
-0.0672 \\
{[0.000529]}\end{array}$ & $\begin{array}{c}0.939 \\
-0.06 \\
{[0.000525]}\end{array}$ & $\begin{array}{c}0.930 \\
-0.0723 \\
{[0.000597]}\end{array}$ \\
\hline $\begin{array}{l}\text { Education Specific } \\
\text { Long-term Income }\end{array}$ & $\begin{array}{c}11.9 \\
2.47 \\
{[0.0175]}\end{array}$ & $\begin{array}{c}22.6 \\
3.12 \\
{[0.0177]}\end{array}$ & $\begin{array}{c}18.8 \\
2.93 \\
{[0.0174]}\end{array}$ & $\begin{array}{c}8.66 \\
2.16 \\
{[0.0190]}\end{array}$ & \\
\hline State is State of Birth & $\begin{array}{c}28.4 \\
3.35 \\
{[0.00566]}\end{array}$ & & & & \\
\hline State is in Division of Birth & $\begin{array}{c}2.70 \\
0.992 \\
{[0.00674]}\end{array}$ & $\begin{array}{c}3.34 \\
1.21 \\
{[0.00618]}\end{array}$ & $\begin{array}{c}4.29 \\
1.46 \\
{[0.00565]}\end{array}$ & $\begin{array}{c}4.46 \\
1.49 \\
{[0.00570]}\end{array}$ & $\begin{array}{c}3.66 \\
1.30 \\
{[0.00605]}\end{array}$ \\
\hline Coastal State & & & & $\begin{array}{c}1.55 \\
0.440 \\
{[0.00447]}\end{array}$ & \\
\hline Long-term State-to-State Flo & & $\begin{array}{c}3750 \\
8.23 \\
{[0.0138]}\end{array}$ & & & \\
\hline Education-specific Long-ter & lows & & $\begin{array}{c}1098 \\
7.00 \\
{[0.0123]}\end{array}$ & $\begin{array}{c}1215 \\
7.10 \\
{[0.0124]}\end{array}$ & $\begin{array}{c}1098 \\
7.00 \\
{[0.0131]}\end{array}$ \\
\hline State Fixed Effects & No & No & No & No & Yes \\
\hline
\end{tabular}


Notes: Data are from 1980, 1990 and 2000 IPUMS, and Raven Saks. Sample consists of 24-30 year olds with positive earnings in the past year. LD index construction described in text. All estimates significant at the $1 \%$ level with the exception of the interaction of dropout with the employment growth measure, which is not significant. All estimations include interactions of demographic variables (black, Hispanic, and female) with EG Index. Standard errors are in brackets. 
Table 4: Wage Effects of Early Labor Market Conditions

\section{Dependent variable: Log Hourly Wage}

\begin{tabular}{|c|c|c|c|c|c|}
\hline Sample: & All 24-30 Year Olds & All 24-30 Year Olds & Non-movers & Movers & Movers \\
\hline LD Index Refers to Conditions in: & State of Birth & State of Birth & State of Birth & State of Birth & State of Residence \\
\hline \multirow{2}{*}{ LD Index } & 0.026 & 0.044 & 0.07 & -0.026 & 0.085 \\
\hline & {$[0.016]$} & {$[0.018]^{*}$} & {$[0.022]^{\star *}$} & {$[0.018]$} & {$[0.029]^{* *}$} \\
\hline \multirow[t]{2}{*}{ LD Index x Dropout } & & -0.043 & -0.056 & -0.006 & -0.013 \\
\hline & & {$[0.021]^{*}$} & {$[0.021]^{\star *}$} & {$[0.035]$} & {$[0.036]$} \\
\hline \multirow[t]{2}{*}{ LD Index x Some College } & & -0.009 & -0.009 & 0.007 & -0.052 \\
\hline & & {$[0.015]$} & {$[0.017]$} & {$[0.027]$} & {$[0.031]$} \\
\hline \multirow{2}{*}{ LD Index x College Grad } & & -0.05 & -0.06 & 0.002 & -0.068 \\
\hline & & {$[0.012]^{\star *}$} & {$[0.015]^{\star *}$} & {$[0.020]$} & {$[0.027]^{*}$} \\
\hline \multirow[t]{2}{*}{ Dropout } & -0.206 & -0.194 & -0.217 & -0.13 & -0.143 \\
\hline & {$[0.017]^{* *}$} & {$[0.018]^{\star *}$} & {$[0.022]^{* *}$} & {$[0.029]^{* *}$} & {$[0.028]^{\star *}$} \\
\hline \multirow[t]{2}{*}{ Some College } & 0.1 & 0.102 & 0.105 & 0.091 & 0.11 \\
\hline & {$[0.012]^{* *}$} & {$[0.014]^{\star *}$} & {$[0.017]^{\star *}$} & {$[0.021]^{\star *}$} & {$[0.022]^{* *}$} \\
\hline \multirow[t]{2}{*}{ College Graduate } & 0.274 & 0.287 & 0.283 & 0.271 & 0.306 \\
\hline & {$[0.012]^{\star *}$} & {$[0.012]^{\star *}$} & {$[0.013]^{* *}$} & {$[0.017]^{* *}$} & {$[0.023]^{* *}$} \\
\hline \multirow[t]{2}{*}{ Black } & -0.07 & -0.07 & -0.093 & -0.023 & -0.044 \\
\hline & {$[0.007]^{* *}$} & {$[0.007]^{\star *}$} & {$[0.012]^{\star *}$} & {$[0.009]^{*}$} & {$[0.008]^{\star *}$} \\
\hline \multirow[t]{2}{*}{ Hispanic } & -0.019 & -0.019 & -0.036 & 0.001 & -0.025 \\
\hline & {$[0.021]$} & {$[0.021]$} & {$[0.026]$} & {$[0.007]$} & {$[0.014]$} \\
\hline \multirow[t]{2}{*}{ Female } & -0.213 & -0.213 & -0.22 & -0.197 & -0.197 \\
\hline & {$[0.007]^{\star *}$} & {$[0.007]^{\star \star}$} & {$[0.009]^{\star \star}$} & {$[0.006]^{\star *}$} & {$[0.008]^{* *}$} \\
\hline \multicolumn{6}{|l|}{ Fixed Effects: } \\
\hline State $\mathrm{x}$ Education & Yes & Yes & Yes & Yes & Yes \\
\hline Year of Birth $x$ Education & Yes & Yes & Yes & Yes & Yes \\
\hline Year & Yes & Yes & Yes & Yes & Yes \\
\hline $\mathrm{N}$ observations & 479981 & 479981 & 323250 & 156731 & 156731 \\
\hline R-squared & 0.12 & 0.12 & 0.13 & 0.13 & 0.14 \\
\hline
\end{tabular}

Notes: Data are from 1980, 1990 and 2000 IPUMS and Raven Saks. LD Index construction described in text. Standard errors clustered at the birth state level are in brackets. ${ }^{*}$ indicates significant at the $5 \%$ level, ${ }^{* *}$ at the $1 \%$ level. 


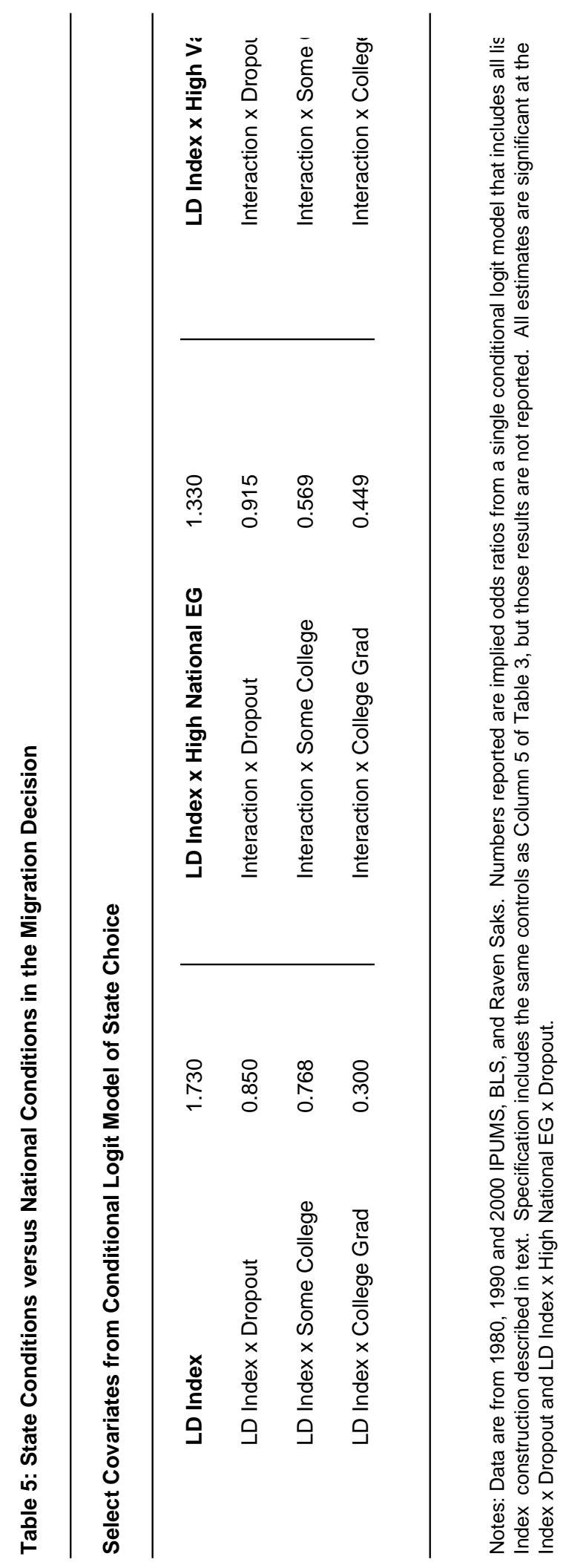




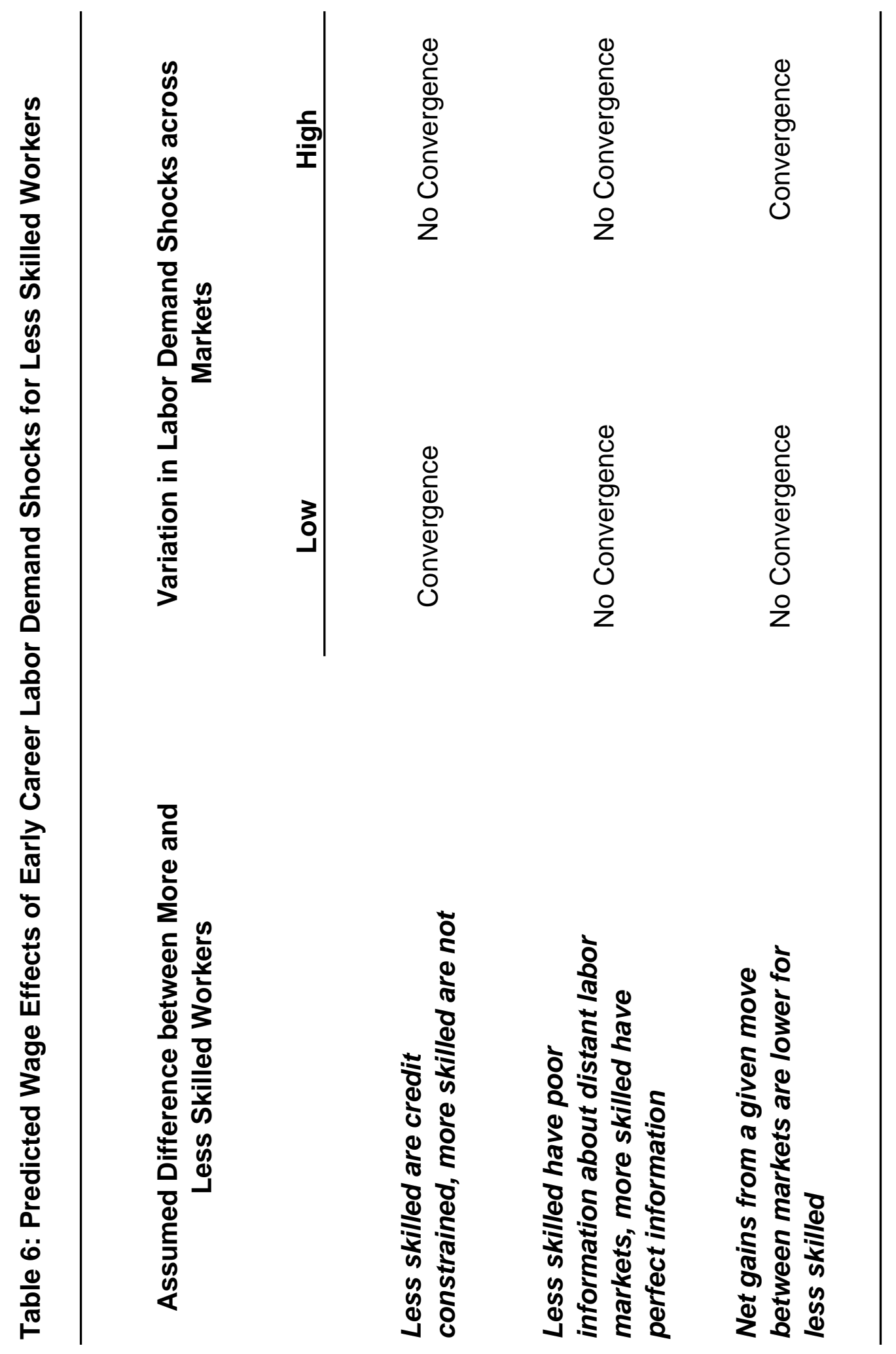




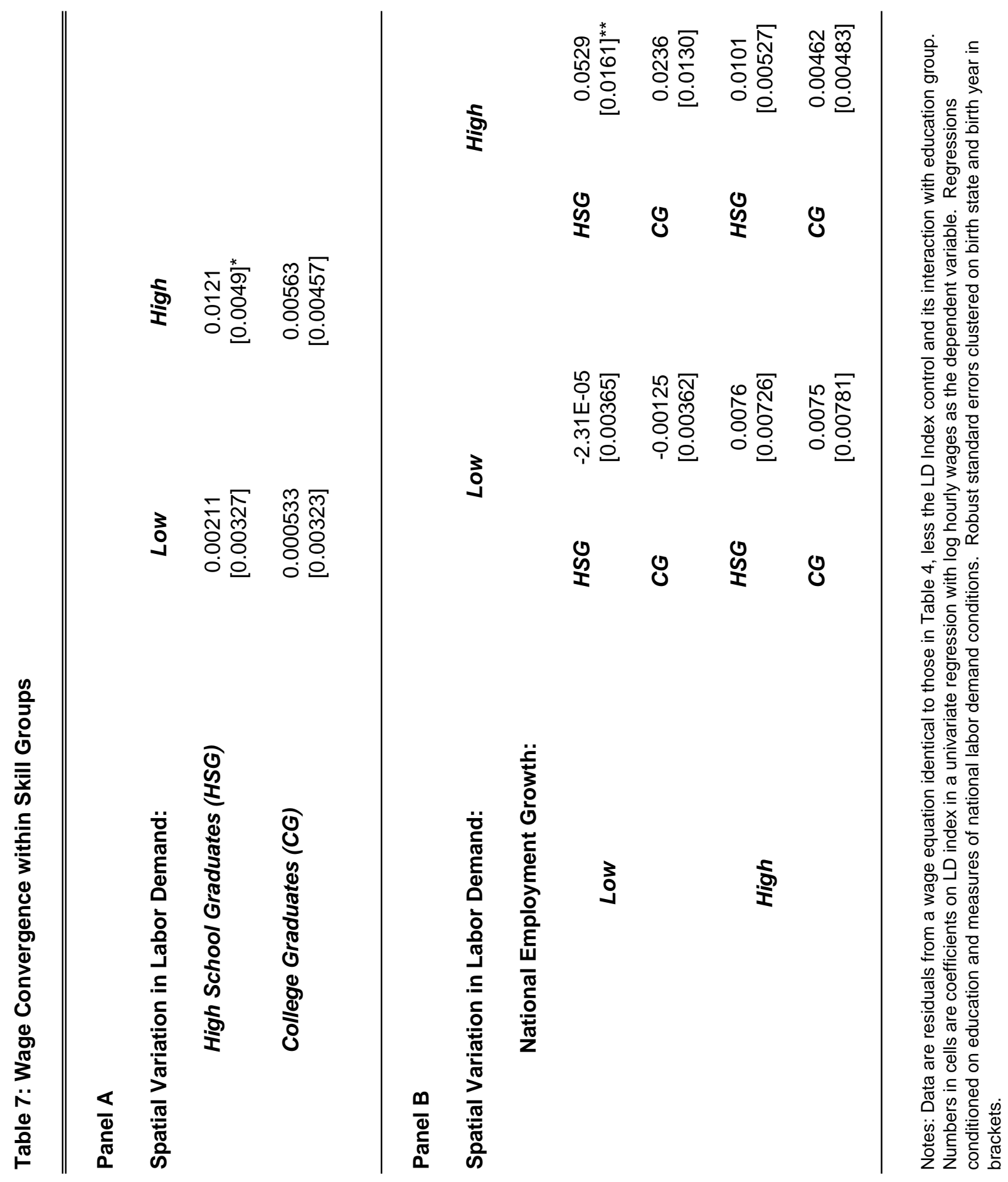

